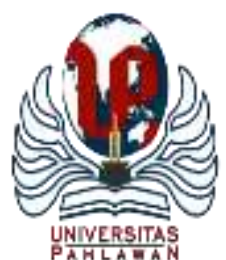

Edukatif : Jurnal Ilmu Pendidikan Volume 3 Nomor 6 Tahun 2021 Halm 4493 - 4505 EDUKATIF: JURNAL ILMU PENDIDIKAN

Research \& Learning in Education

https://edukatif.org/index.php/edukatif/index

\title{
Evaluasi Pemanfaatan E-Learning pada Pembelajaran Teori di Prodi Kebidanan Fakultas Kedokteran Undiksha
}

\section{Ni Ketut Erawati ${ }^{1 凶}$, Made Juliani², Ni Wayan Dewi Tarini ${ }^{3}$}

Universitas Pendidikan Ganesha, Indonesia ${ }^{1,2,3}$

E-mail : ketut.erawati@undiksha.ac.id ${ }^{1}, \underline{\text { made.juliani@undiksha.ac.id }}^{2}, \underline{\text { wayan.dewitarini@ undiksha.ac.id }}^{3}$

\begin{abstract}
Abstrak
Penelitian ini bertujuan untuk menilai pelaksanaan pembelajaran teori berbasis e-learning di Prodi Kebidanan Undiksha dengan menggunakan model evaluasi Contex, Input, Process dan Product (CIPP). Penelitian ini menggunakan metode kuantitatif dengan teknik analisis data secara deskriptif. Sampel yang digunakan pada penelitian ini adalah dosen dan mahasiswa yang berjumlah 56 orang. Hasil penelitian menunjukkan bahwa pelaksanaan pembelajaran berbasis $e$-learning pada komponen context pada indikator tujuan, kebutuhan dan lingkungan pendukung berada pada kategori baik dengan rerata persentase sebesar $62.1 \%$. Pada komponen input yang terdiri dari indikator latar belakang pendidik, mahasiswa, ketersediaan sarana prasarana dan ketersediaan perangkat pembelajaran juga berada pada kategori baik dengan rerata persentase adalah 59.6\%. Begitu pula halnya pada komponen process pada indikator pelaksanaan pembelajaran, aktivitas pendidik dan mahasiswa, kendala dan hambatan serta solusi yang ditempuh berada pada kategori baik dengan rerata persentase sebesar $63.75 \%$. Komponen product yang meliputi hasil pembelajaran dan dampak juga berada pada kategori baik dengan rerata persentase $63.77 \%$. Dari hasil penelitian dapat disimpulkan bahwa pelaksanaan pembelajaan teori dengan menggunakan e-learning di Prodi Kebidanan Undiksha secara keseluruhan sudah berjalan dengan baik artinya pemanfaatan e-learning dalam pembelajaran dapat dilanjutkan.
\end{abstract}

Kata Kunci: Evaluasi CIPP, E- Learning, Pembelajaran Teori.

\begin{abstract}
This study aims to assess the implementation of e-learning-based theory learning in the Undiksha Midwifery Study Program using the Contex, Input, Process and Product (CIPP) evaluation model. This study uses quantitative methods with descriptive data analysis techniques. The sample used in this study were lecturers and students, totaling 56 people. The results showed that the implementation of e-learning based learning on the context component of the indicators of goals, needs and supporting environment were in the good category with an average percentage of 62.1\%. The input component consisting of indicators of the background of educators, students, availability of infrastructure and availability of learning equipment is also in the good category with the average percentage of 59.6\%. Likewise, the process component of the indicators of the implementation of learning, the activities of educators and students, obstacles and obstacles as well as the solutions taken are in the good category with an average percentage of 63.75\%. Product components which include learning outcomes and impacts are also in the good category with an average percentage of 63.77\%. From the results of the study, it can be concluded that the implementation of theory learning using e-learning in the Undiksha Midwifery Study Program has been running well, meaning that the use of e-learning in learning can be continued.
\end{abstract}

Keywords: CIPP Evaluation, E-Learning, Learning Theory.

Copyright (c) 2021 Ni Ketut Erawati, Made Juliani, Ni Wayan Dewi Tarini

$\triangle$ Corresponding author

Email : ketut.erawati@undiksha.ac.id

DOI : https://doi.org/10.31004/edukatif.v3i6.1462

ISSN 2656-8063 (Media Cetak)

ISSN 2656-8071 (Media Online)

Edukatif : Jurnal Ilmu Pendidikan Vol 3 No 6 Tahun 2021 p-ISSN 2656-8063 e-ISSN 2656-8071 


\section{PENDAHULUAN}

Sistem pembelajaran jarak jauh berbasis digital sebenarnya sudah ada sejak lama. Berbagai model pembelajaran jarak jauh seperti blended learning, flipp classroom, dengan beragam aplikasi media pembelajaran yang tersedia, bukanlah sesuatu yang baru, hanya saja memang dalam pemanfaatannya belum optimal. Pembelajaran dalam situasi normal baik di sekolah ataupun dikampus masih lebih banyak didominasi oleh tatap muka secara langsung. Hasil penelitian menunjukkan bahwa mayoritas mahasiswa (93.5\%) lebih menyukai pembelajaran secara offline dikelas tatap muka dibandingkan pembelajaran daring (Ningsih, 2020). Namun tidak pada situasi seperti sekarang ini. Situasi pandemi Covid-19 saat ini memaksa kita untuk bertransformasi termasuk dibidang pendidikan. Proses pembelajaran yang senyatanya bisa dilakukan secara tatap muka langsung harus bergeser ke pembelajaran berbasis digital atau dengan kata lain diselenggarakan secara daring. Salah satu media pembelajaran daring adalah pemanfaatan e-learning. Pembelajaran di masa pandemi yang diselenggarakan jarak jauh menuntut seluruh komponen pendidikan yang terlibat didalamnya mulai dari dosen, mahasiswa, keluarga ikut andil dan memegang peranan penting dalam prosesnya, dan menuntut kita untuk belajar dan terus belajar tentang pemanfaatan teknologi dalam pembelajaran. Dalam prosesnya pembelajaran dengan memanfaatkan media e-learning ini tentu memerlukan pemantauan, tidak hanya untuk melihat apakah proses pembelajaran yang terjadi betul-betul efektif dan apakah capaian pembelajarannya terpenuhi. Namun sejauh ini di Prodi D3 Kebidanan khususnya belum pernah dilakukan evaluasi penyelenggaraan proses belajar dengan e-learning ini.

E-learning secara umum dapat diartikan sebagai suatu sistem atau konsep pendidikan yang memanfaatkan suatu teknologi informasi dalam proses belajar mengajar. Tentu dengan memanfaatkan teknologi ini pembelajaran ini dapat dilakukan oleh siapapun dan dapat diakses dimanapun dan kapanpun sepanjang didukung oleh jaringan internet yang memadai. Sebenarnya metode e-learning ini bukan saja merupakan metode pembelajaran jarak jauh saja namun bisa juga dipadupadankan dengan pembelajaran konvensional, sehingga pembelajaran menjadi lebih interaktif. Pembelajaran baik secara tatap muka, $e$ learning, maupun kombinasi keduanya, adalah proses yang melibatkan 3 aktivitas yang saling berkaitan satu sama lain, yakni: (1) aktivitas presentasi, yaitu pemaparan atau penyajian bahan pembelajaran, (2) aktivitas interaksi, yaitu aktivitas komunikasi timbal balik antara pembelajar dengan fasilitator maupun antar pembelajar, dan (3) aktivitas evaluasi yang berfungsi sebagai pengukur kemajuan dan keberhasilan pembelajaran (Wibawanto, 2017).

Meskipun bukan merupakan sesuatu yang baru, namun dalam prakteknya proses pembelajaran dengan menggunakan media e-learning masih banyak menemui kendala. Minimnya kegiatan pelatihan tentang pembelajaran daring yang diikuti oleh dosen menjadi salah satu faktor yang memperlemah terselenggaranya proses pembelajaran daring ini dengan baik. Kendala dari segi pengajar yang belum memahami betul bagaimana membuat setting pembelajaran melalui e-learning, mulai dari membuat media pembelajarannya, membuat forum interaktif melaui ruang diskusi yang ada pada laman aplikasi serta proses evaluasinya baik berupa input test akhir atau quiz. Meskipun sudah lama digaungkan dalam dunia pendidikan namun hal ini masih saja terdengar asing dan dosen perlu menyiapkan waktu lebih untuk mempersiapkan pembelajaran secara daring ini. Metode e-learning dengan paltform beragam seperti google classroom, edmodo, moodle, kahoot dan masih banyak lagi nampaknya membuat pengajar mengalami kesulitan dalam pengaplikasiannya.

Permasalahan mengenai $e$-learning ini tidak hanya dari kalangan dosen saja tetapi juga dari mahasiswa. Mahasiswa dengan latar belakang yang berbeda-beda tentu menjadi suatu pertimbangan dalam penyelenggaraan proses pembelajaran secara e-learning. Maka dari itu perlu diadakan suatu analisis pebelajar sebelumnya. Selain masalah diatas faktor infrastruktur juga harus mendukung. Support internet yang mencukupi menjadi modal utama lancarnya proses pembelajaran dengan e-learning ini. Di Prodi D3 Kebidanan Undiksha telah dilengkapi dengan dukungan fasilitas internet yang memadai untuk proses belajar 
mengajar dilingkungan kampus, namun oleh karena situasi pandemi seperti saat ini maka pembelajaran harus dilakukan dari rumah masing-masing. Hal ini tentu sangat tergantung pada kesiapan fasilitas baik yang dimiliki oleh mahasiswa maupun dosen.

Kondisi dengan sistem belajar dari rumah (BDR) mengharuskan kita semua baik dosen maupun mahasiswa untuk melakukan pembelajaran jarak jauh dengan metode e-learning. Di tingkat lembaga pun sebenarnya layanan pembelajaran melalui e-learning sudah tersedia melalui layanan Single Sign On (SSO) Undiksha yang dapat diakses baik oleh dosen maupun mahasiswa yang melakukan pembelajaran dengan menggunakan sistem e-learning undiksha. Berdasarkan pemasalahan yanga ada, perlu diambil suatu solusi pemecahan yang dapat direkomendasikan oleh pemangku kebijakan sehingga kedepannya pelaksanaan program dapat lebih disempurnakan kembali sesuai dengan tujuan. Rekomendasi yang baik dapat diterjadikan melalui adanya proses evaluasi yang baik dan dijalankan sesuai dengan kriteria-kriteria yang telah ditetapkan dengan mengacu pada komponen evaluasi, sehingga dapat ditemukan kendala-kendala yang memang benarbenar perlu disempurnakan atau diperbaiki (Gede \& Divayana, n.d.).

Selama ini belum pernah dilakukan evaluasi mengenai pelaksanaan pembelajaran berbasis e-learning khsusnya di Prodi D3 Kebidanan Undiksha, padahal disisi lain evaluasi pembelajaran daring penting dilakukan untuk memperbaiki kualitas dan mutu pembelajaran (Riyanda et al., 2020). Dengan adanya evaluasi, diharapkan dapat diketahui pelaksanaan pembelajaran e-learning. Dengan penilaian dapat diperoleh informasi yang akurat tentang penyelenggaraan pembelajaran dan keberhasilan belajar siswa diukur dan dilaporkan berdasarkan pencapaian kompetensi tertentu (Oemar Hamalik, 2009). Suatu evaluasi dikatakan baik jika mempunyai kriteria evaluasi itu baik menurut Smith dalam Bhakti (2017) adalah validitas, obyektifitas, practicability. Dari evaluasi yang baik itulah akan dapat memberi motivasi baik kepada siswa maupun kepada guru. Kegiatan evaluasi yang peneliti gunakan mencakup dari segi konteks, input, proses, produk. Penilaian yang dilakukan selanjutnya merupakan informasi yang dapat dipercaya sebagai dasar dalam pengambilan putusan terkait dengan penyelenggaraan e-learning sebagai salah satu media pembelajaran yang digunakan saat ini

Penelitian tentang evaluasi pemanfaatan e-learning telah banyak dilakukan termasuk salah satunya adalah penelitian yang dilakukan oleh Gede \& Divayana (n.d.) tentang "Evaluasi Pemanfaatan E-Learning dengan Menggunakan Model USE-UCLA" persamaannya adalah pada jenis penelitian yaitu evaluatif sedangkan perbedaannya terletak pada model evaluasi yang digunakan. Model evaluasi yang digunakan pada penelitian tersebut adalah model USE-UCLA sedangkan pada penelitian ini menggunakan model evaluasi CIPP. Penelitian lain yang dilakukan oleh Rahman et.al (2020) tentang "Evaluasi Penerapan Model pembelajaran E-Learning Pada Pelatihan Dasar Calon Pegawai Negeri Sipil" memiliki persamaan dalam hal mengevaluasi suatu program, namun perbedaannya terletak pada model evaluasi yang digunakan, pada penelitian tersebut hasil evaluasi disampaikan secara deskriptif kualitatif sedangkan pada penelitian ini hasil evaluasi disajikan dengan model CIPP. Begitu juga penelitian yang dilakukan oleh Syswianti e.al (2020) tentang "Evaluasi Pembelajaran Daring dengan Menggunakan Aplikasi Zoom di Masa Pandemi Covid-19 pada Mata Kuliah Pengantar Asuhan Kebidanan" memiliki unsur kesamaan pada topik penelitian yaitu tentang evaluasi pembelajaran dan perbedaannya terletak pada model evaluasi yang digunakan, pada penelitian tersebut hasil evaluasi disampaikan secara deskriptif kualitatif. Jika dilihat dari beberapa penelitian diatas secara umum dapat dibedakan dengan penelitian ini yakni dari segi komponen yang terlibat. Pada penelitian ini akan dilihat secara spesifik dari penyelenggaraan sebuah program yakni pembelajaran melalui $e$ learning mulai dari segi konteks, input, proses dan produknya, sehingga dengan metode CIPP ini nantinya bisa memberi gambaran secara mendetail dan akuntabel baik dari segi proses maupun diakhir proses pembelajaran.

Dari pemaparan diatas maka pada penelitian ini peneliti ingin mengetahui lebih mendalam pelaksanaan pembelajaran berbasis e-learning di Prodi D3 Kebidanan ditinjau dari segi Konteks, Input, Proses dan Produk. 


\section{METODE PENELITIAN}

Penelitian ini termasuk dalam jenis penelitian deskriptif. Penelitian deskriptif dengan metode evaluatif pada dasarnya merupakan kegiatan penelitian untuk mengumpulkan data, menyajikan informasi untuk mendeskripsikan keadaan yang sesungguhnya terjadi dilapangan mengenai pelaksanaan suastu program, menarik kesimpulan berdasarkan kriteria yang ditetapkan, serta memberikan makna hasil terhadap hasil penelitian agar bermanfaat untuk pemecahan masalah yang dihadapi.

Sampel pada penelitian ini diambil secara purposive sampling artinya sampel pada penelitian ini dipilih berdasarkan kriteria yang ditetapkan oleh peneliti Adapun sampel penelitiannya adalah1 orang koorprodi, 13 orang dosen dan mahasiswa Prodi D3 Kebidanan. Adapun kriteria inklusi sampel adalah:

1) Mahasiswa pernah mengikuti perkuliahan teori secara luring pada semester sebelumnya dan daring pada saat ini

2) Mahasiswa Prodi D3 Kebidanan semester IV yang secara kurikulum mendapatkan distribusi matakuliah di semester ini lebih banyak pada bobot teori

Kriteria eksklusi sampel adalah mahasiswa yang telah mengikuti pembelajaran klinik (lapangan). Identifikasi variabel penelitian dalam studi evaluasi ini melibatkan empat variabel, yaitu: variable konteks, input, proses dan produk. Metode pengumpulan data yang digunakan pada penelitian ini meliputi kuesioner, yaitu teknik pengumpulan data penelitian dengan menggunakan daftar pertanyaan tertutup yang diberikan pada responden dalam hal ini adalah koorprodi, dosen serta mahasiswa.

Instrumen yang digunakan dalam penelitian ini adalah lembar kuesioner. Angket atau kuesioner adalah sejumlah pertanyaan tertulis yang digunakan untuk memperoleh informasi dari responden dalam arti laporan tentang pribadinya, atau hal-hal yang ia ketahui (Arikunto, 2011).

Instrumen angket/ kuesioner ini digunakan untuk mengetahui dan memperoleh data serta informasi berupa pendapat mahasiswa tentang hasil dari pembuatan media pembelajaran yang telah dibuat untuk dapat dievaluasi dan dikembangkan lebih lanjut agar layak digunakan sebagai media yang menunjang pembelajaran. Dalam pengisian instrumen angket tersebut, objek penelitian akan menyampaikan sikapnya melalui pernyataan tertulis. Oleh karena itu, dalam instrumen ini digunakanlah model skala sikap atau yang sering disebut skala likert. Skala pengukuran instrumen yang digunakan dalam penelitian ini adalah menggunakan skala likert dengan lima pilihan jawaban, yaitu sangat sesuai diberi skor 5, sesuai diberi skor 4, cukup sesuai diberi skor 3, tidak sesuai diberi skor 2, dan sangat tidak sesuai diberi skor 1. Instrumen penelitian ini untuk mengevaluasi program pembelajaran berbasis e-learning dengan kuesioner yang memuat 36 butir pertanyaan tertutup berdasarkan model evaluasi Context, Input, Process, Product (CIPP). Proses pengumpulan data penelitian dengan menggunakan kuesioner ini dilakukan secara daring menggunakan google form.

Validitas instrumen pada penelitian ini akan diuji terlebih dahulu secara teoritis dengan melakukan telaah instrumen berdasarkan masukan oleh para ahli (expert judgement). Penilaian instrument pakar selanjutnya akan dianalisis dengan menggunakan formula Gregory dan didapatkan validitas instrument sangat tinggi.

Penelitian ini menggunakan data kuantitatif yang diperoleh dari variabel konteks, input, proses dan produk, data hasil angket/kuesioner kemudian dianalisis secara deskriptif kuantitatif. Untuk mendeskripsikan atau mengetahui variable konteks, input, proses dan produk digunakan skor, masing-masing aspek dinilai dengan menggunakan skalak likert dimana responden memilih lima jawaban yang tersedia.

\section{1) Rata rata atau Mean (M)}

Mean merupakan teknik penjelasan kelompok yang didasarkan atas nilai rata-rata dari kelompok tersebut. Rata-rata (mean) ini didapat dengan menjumlahkan data seluruh individu dalam kelompok itu, kemudian dibagi dengan jumlah individu yang ada pada kelompok tersebut, hal ini dapat dirumuskan sebagai berikut. 


$$
M=\frac{\sum X}{N}
$$

$$
\begin{aligned}
& M=\text { Mean (rata-rata) } \\
& \sum=\text { Epsilon (Jumlah) } \\
& X=\text { Nilai } x \text { ke } 1 \text { sampai ke-n } \\
& \mathrm{N}=\text { jumlah Data } \\
& \text { Sumber }: \text { (Sugiyono, 2011) }
\end{aligned}
$$

\section{2) Standar Deviasi (SD)}

Standar deviasi adalah rata-ratakuadrat penyimpanan masing-masing sor individu dari mean kelompok. Rumus perhitungan simpangan baku sebagai berikut.

$$
\mathrm{SD}=\sqrt{\frac{\sum f i\left(x_{i}{ }^{n} x\right)}{n-1}}
$$

Keterangan:

$\mathrm{SD}=$ Standar Deviasi

$\mathrm{f}=$ Frekuensi

$\mathrm{x}=$ Nilai tengah interval tiap kelas

$\mathrm{n}=$ Banyaknya data populasi atau sebuah sampel

Sumber :(Sugiyono, 2011)

Jawaban responden direduksi dan dikategorikan sesuai dengan jawaban angket. Pemberian scoring dibuat dengan skala likert dengan skor 1 sampai 5. Data yang diperoleh melalui angket dinilai dengan melihat ketegorisasi tingkat kecenderungan masing masing variable. Oleh karena itu diperlukan rata rata ideal (Mi) dan simpangan baku ideal (SDi), skor tertinggi ideal dan skor terendah ideal dapat dicapai oleh instrument sebagai kriteria. Menurut Arikunto (2011), pengelompokan tersebut menggunakan rumus yang dapat dilihat pada tabel berikut ini.

Table 1. Pedoman kriteria penilaian

\begin{tabular}{ll}
\hline \multicolumn{1}{c}{ Interval Nilai } & \multicolumn{1}{c}{ Kategori } \\
\hline $\mathrm{X}>\mathrm{Mi}+1,5$ SDi & Sangat Baik Baik \\
$\mathrm{Mi}<\mathrm{X}<\mathrm{Mi}+1,5 \mathrm{SDi}$ Mi-1,5 & Kurang Baik \\
$\mathrm{SDi}<\mathrm{X}<\mathrm{Mi}$ & Buruk \\
$\mathrm{X}<\mathrm{Mi}-1,5 \mathrm{SDi}$ & \\
\hline
\end{tabular}

Keterangan

$\mathrm{Mi}=1 / 2($ skor tertinggi + skor terendah $)$

$\mathrm{SDi}=1 / 6$ (skor tertinggi - skor terendah)

Mi : Mean Ideal

SDi : Simpangan baku ideal

$\mathrm{X}:$ Skor Aktual, Skor tertinggi $=5$, Skor terendah $=1$

$\mathrm{Mi}=1 / 2(5+1)=3$ dan SDi $\quad=1 / 6(5-1)=0.67$

Berdasarkan hasil perhitungan diatas disusun standar skor kategori kecenderungan variabel dan komponen yang dipakai sebagari kriteria dalam evaluasi. Analisis statistik deskriptif menggunakan pernyataan sangat baik, baik, kurang baik dan buruk, seperti pada tabel berikut ini. 
Tabel 2. Kriteria Penilaian

\begin{tabular}{ll}
\hline \multicolumn{1}{c}{ Interval Nilai } & \multicolumn{1}{c}{ Kategori } \\
\hline $\mathrm{X} \geq 4.005$ & Sangat Baik \\
$3 \leq \mathrm{X}<4.005$ & Baik \\
$1.995 \leq \mathrm{X}<3$ & Kurang Baik Buruk \\
$\mathrm{X}<1,995$ & \\
\hline
\end{tabular}

Dilihat dari tabel dapat dijelaskan bahwa instrumen yang telah diisi dicari skor keseluruhan, sehingga setiap sub indikator dari setiap komponen evaluasi memiliki skor. Selanjutnya dicarai rerata skor keseluruhan responden dan simpangan bakunya. Perhitungan dalam analisa data menghasilkan presentase pencapaian yang selanjutnya dilakukan interpretasi. Proses perhitungan presentase dilakukan dengan cara mengalikan hasil bagi skor riil dan skor ideal dengan status persen.

Rumus tingkat pencapaian sebagai berikut.

$$
P_{S}=\frac{\sum P}{\sum 1} \times 100 \%
$$

$$
\begin{array}{ll}
P S & =\text { Persentase } \\
\sum P & =\text { Frekuensi riil } \\
\sum 1 & =\text { Jumlah ideal }
\end{array}
$$

Sumber : (Sugiyono, 2011)

\section{HASIL DAN PEMBAHASAN PENELITIAN}

\section{Hasil Penelitian}

Instrumen penelitian berupa kuesioner/ angket yang meliputi kompoen Context, Input, Process dan Product sebelumnya telah melalui uji validitas isi melalui expert judgement, dan didapatkan hasil sebagai berikut.

1) Analisis Evaluasi Konteks

Evaluasi konteks yang dievaluasi pada penelitian ini meliputi 3 indikator yaitu: 1) tujuan pembelajaran, 2) kebutuhan terhadap pelaksanaan program, 3) lingkungan pendukung terlaksananya program pembelajaran. Dari hasil analisis data penelitian didapatkan data variabel konteks sebagai berikut. Pertama indicator tujuan pembelajaran Sebagian besar berada pada kategori baik sebesar 69.05\%. Kedua, indicator kebutuhan terhadap pelaksanaan program sebagian besar dengan kategori baik sebanyak $60.12 \%$ dan yang ketiga indicator lingkungan pendukung pelaksaan pembelajaran sebanyak $57.14 \%$ termasuk pada kategori baik. Untuk memperjelas data diatas dapat dilihat pada tabel berikut ini.

Tabel 3. Distribusi responden berdasarkan variable konteks

\begin{tabular}{llcccccccc}
\hline No & Indikator & \multicolumn{8}{c}{ Kategori } \\
\cline { 2 - 10 } & $\begin{array}{c}\text { Sangat } \\
\text { baik }\end{array}$ & \% & Baik & \% & $\begin{array}{c}\text { Kurang } \\
\text { baik }\end{array}$ & \% & Buruk & \% \\
\hline 1 & $\begin{array}{l}\text { Tujuan } \\
\text { Pembelajaran }\end{array}$ & 26 & 15.48 & 116 & 69.05 & 22 & 13.1 & 4 & 2.38 \\
\hline 2 & $\begin{array}{l}\text { Kebutuhan thd } \\
\text { pelaksanaan } \\
\text { program }\end{array}$ & 34 & 20.24 & 101 & 60.12 & 29 & 17.26 & 4 & 2.38 \\
\hline 3 & Lingkungan & 34 & 20.24 & 96 & 57.14 & 28 & 16.67 & 10 & 5.95 \\
\hline
\end{tabular}




\begin{tabular}{ccccc}
\hline pendukung & & & & \\
\hline Rata-rata & 18.65 & 62.10 & 15.68 & 3.57 \\
\hline
\end{tabular}

\section{2) Analisis Evaluasi Input}

Evaluasi masukan di arahkan pada hal-hal yang mendukung terselenggaranya pembelajaran dengan $e$ learning meliputi: 1) latar belakang dan kompetensi pendidik, 2) latar belakang dan kemampuan mahasiswa, 3) ketersediaan sarana dan prasarana penunjang pembelajaran, 4) ketersediaan perangkat pembelajaran.

Data penelitian khususnya pada variabel input menunjukkan hasil sebagai berikut.Pertama indicator latar belakang pendidik atau dosen sebagian besar yakni $56.25 \%$ berada pada kategori baik. Kedua jika ditinjau dari latar belakang kemampuan mahasiswa sebagian besar mahasiswa yakni sebanyak $66.07 \%$ termasuk pada kategori baik. Ketiga jika dilihat dari indicator ketersediaan sarana prasarana pendukung pelaksanaan pembelajaran dengan $e$ - learning didapatkan sebanyak 52.68\% termasuk pada kategori baik dan indicator keempat yakni ketersediaan perangkat berupa silabus dan rencana pembelajaran sebagian besar juga berada pada katergori baik yaitu $63.39 \%$.

Tabel 4. Distribusi responden berdasarkan variable input

\begin{tabular}{cccccccccc}
\hline No & Indikator & \multicolumn{7}{c}{ Kategori } \\
\cline { 3 - 10 } & & $\begin{array}{c}\text { Sangat } \\
\text { baik }\end{array}$ & $\mathbf{\%}$ & Baik & $\mathbf{\%}$ & $\begin{array}{c}\text { Kurang } \\
\text { baik }\end{array}$ & \% & Buruk & \% \\
\hline 1 & Latkang Dosen & 16 & 14.29 & 63 & 56.25 & 25 & 22.32 & 8 & 7.14 \\
\hline 2 & Latkang Mhs & 18 & 16.07 & 74 & 66.07 & 16 & 14.29 & 4 & 3.57 \\
\hline 3 & Sarpras & 35 & 31.25 & 59 & 52.68 & 13 & 11.61 & 5 & 4.46 \\
\hline 4 & $\begin{array}{c}\text { Perangkat } \\
\text { pembelajaran }\end{array}$ & 35 & 31.25 & 71 & 63.39 & 6 & 5.36 & 0 & - \\
\hline & Rata-rata & & $\mathbf{2 3 . 2 2}$ & & $\mathbf{5 9 . 6}$ & & $\mathbf{1 3 . 3 9}$ & & $\mathbf{3 . 7 9}$ \\
\hline
\end{tabular}

\section{3) Analisis Evaluasi Proses}

Evaluasi proses dalam kegiatan pembelajaran, seberapa jauh e-learning terlaksana, adapun yang diamati meliputi: 1) proses pembelajaran berbasis e-learning meliputi: penyampaian materi, penyampaian tugas dan pelaksanaan evaluasi dengan menggunakan e-learning, 2) aktivitas pendidik meliputi metode pembelajaran yang digunakan, kemampuan dosen dalam menggunakan teknologi, 3) aktivitas mahasiswa meliputi sikap dan minat mahasiswa dalam pembelajaran, 4) kendala dan hambatan dalam pelaksanaan pembelajaran dengan e-learning meliputi masalah yang terjadi dalam pembelajaran dan masalah terkait perangkat penunjang pembelajaran, 5) Solusi berupa strategi pemecahan masalah dari segi sarana dan prasarana serta strategi pemecahan masalah dari segi pengetahuan/ kemampuan sumber daya.

Adapun hasil analisis data pada variabel proses adalah sebagai berikut.

Jika dilihat dari proses pembelajaran via e-learning sebagian besar termasuk kategori baik yakni $67.26 \%$. Aktivitas pendidik dalam pelaksanaan pembelajaran e-learning sebagian besar termasuk kategori baik sebanyak $77.67 \%$, aktivitas mahasiswa sebanyak $68.45 \%$ termasuk kategori baik, kendala dan hambatan yang dijumpai dalam pelaksanaan e-learning sebanyak $49.1 \%$ termasuk kategori baik dan solusi yang diharapkan untuk memperlancar proses pembelajaran e-learning sebagian besar yakni 56.25\% termasuk kategori baik.

Tabel 5. Distribusi responden berdasarkan variable proses

\begin{tabular}{cccccccccc}
\hline No & Indikator & \multicolumn{9}{c}{ Kategori } \\
\cline { 3 - 11 } & & $\begin{array}{c}\text { Sangat } \\
\text { baik }\end{array}$ & \% & Baik & \% & $\begin{array}{c}\text { Kurang } \\
\text { baik }\end{array}$ & \% & Buruk & \% \\
\hline 1 & Proses pembelajaran & 23 & 13.69 & 113 & 67.26 & 24 & 14.28 & 8 & 4.76 \\
\hline 2 & Aktivitas pendidik & 20 & 17.85 & 87 & 77.67 & 5 & 4.46 & 0 & 0 \\
\hline
\end{tabular}


4500 Evaluasi Pemanfaatan E-Learning pada Pembelajaran Teori di Prodi Kebidanan Fakultas Kedokteran Undiksha - Ni Ketut Erawati, Made Juliani, Ni Wayan Dewi Tarini

DOI: https://doi.org/10.31004/edukatif.v3i6.1462

\begin{tabular}{cccccccccc}
\hline 3 & Aktivitas mhs & 16 & 9.52 & 115 & 68.45 & 29 & 17.26 & 8 & 4.76 \\
\hline 4 & Kendala & 9 & 8.03 & 55 & 49.1 & 31 & 27.67 & 17 & 15.17 \\
\hline 5 & solusi & 45 & 40.17 & 63 & 56.25 & 2 & 1.78 & 2 & 1.78 \\
\hline Rata-rata & & $\mathbf{1 7 . 8 5}$ & & $\mathbf{6 3 . 7 5}$ & & $\mathbf{1 3 . 0 9}$ & & $\mathbf{5 . 2 9}$ \\
\hline
\end{tabular}

\section{4) Analisis Evaluasi Produk}

Evaluasi produk pada penelitian ini meliputi: 1) Hasil meliputi capaian akhir pembelajaran serta pelaksanaan pembelajaran yang tepat waktu, 2) Dampak baik pada pengembangan pembelajaran, bagi dosen dan bagi mahasiswa.

Hasil analisis data penelitian pada variabel produk menunjukkan hasil sebagai berikut. Indikator pertama yakni hasil pembelajaran didapatkan bahwa $63.69 \%$ termasuk kategori baik dan indikator kedua yakni dampak pembelajaran dengan e-learning termasuk pada kategori baik yakni $63.84 \%$.

Tabel 6. Distribusi responden berdasarkan variable produk

\begin{tabular}{|c|c|c|c|c|c|c|c|c|c|}
\hline \multirow[t]{2}{*}{ No } & \multirow[t]{2}{*}{ Indikator } & \multicolumn{8}{|c|}{ Kategori } \\
\hline & & $\begin{array}{c}\text { Sangat } \\
\text { baik }\end{array}$ & $\%$ & Baik & $\%$ & $\begin{array}{c}\text { Kurang } \\
\text { baik }\end{array}$ & $\%$ & Buruk & $\%$ \\
\hline 1 & Hasil Belajar & 31 & 18.45 & 107 & 63.69 & 24 & 14.28 & 6 & 3.57 \\
\hline 2 & Dampak & 53 & 23.66 & 143 & 63.84 & 23 & 10.26 & 5 & 2.23 \\
\hline & Rata-rata & & 21.06 & & 63.77 & & 12.27 & & 2.9 \\
\hline
\end{tabular}

\section{Pembahasan}

1) Evaluasi Konteks

Hasil yang didapatkan pada masing-masing indikator komponen konteks menunjukkan bahwa sistem pembelajaran dengan e-learning yang dilaksanakan di Prodi D3 Kebidanan Undiksha sudah tergolong baik. Dari tiga indicator yang diukur pada komponen konteks yakni tujuan pembelajaran, kebutuhan akan pembelajaran e-learning dan lingkungan pendukung, semua indikator tersebut berada pada kategori baik, meskipun masih terdapat indicator yang mengalami kendala yakni pada indicator lingkungan pendukung, support jaringan yang kurang mumpuni serta sarana pendukung lainnya seperti kuota, sharing room, kepemilikan smartphone. Meskipun demikian diharapkan pemegang kebijakan mampu memberikan solusi terhadap permasalahan ini. Hal ini sejalan dengan yang disampaikan oleh Sanders dalam (Arikunto, 2008) yang mengatakan bahwa evaluasi konteks merupakan dasar evaluasi yang bertujuan menyediakan alasanalasan dalam penentuan tujuan. Oleh karenanya upaya yang dilakukan oleh seorang evaluator dalam evaluasi konteks ini adalah memberikan gambaran dan rincian terhadap lingkungan, kebutuhan serta tujuan. Pembelajaran dengan e-learning disatu sisi memang menawarkan kemudahan yakni bisa dilakukan dimana dan kapan saja, namun disisi lain membutuhkan system pendukung yang memadai agar hasilnya bisa optimal. Dalam kaitannya dengan lingkungan tetntu pebelajar membutuhkan situasi yang kondusif seperti kemudahan mengakses signal internet, ruangan yang tersendiri dan ketersediaan kuota internet sehingga memudahkan mahasiswa dalam mengikuti pembelajaran. Mahasiswa Prodi D3 Kebidanan Undiksha mayoritas berasal dan tinggal di Bali, hanya beberapa mahasiswa saja yang tinggal di luar pulau, dengan kondisi geografis alam Bali hanya beberapa daerah saja yang sulit mengakses jaringan internet. Dari ketiga hal tersebut sangat dimungkinkan untuk memberikan bantuan berupa kuota belajar bagi mahasiswa agar tidak ada hambatan lagi bagi mahasiswa untuk dapat mengakses pembelajaran. Hal ini sejalan dengan hasil penelitian yang dilakukan oleh (Islam et al., 2021) yang mengatakan bahwa selama menjalani proses pembelajaran online, banyak siswa yang mengalami kesulitan ketika melakukan pembelajaran secara online diantaranya susahnya mengakses internet yang kurang memadai. Kuota merupakan sumber masalah berikutnya dimana jika tidak menggunakan wifi dirumahnya maka siswa harus mengeluarkan uang lebih untuk membeli kuota internet. 


\section{2) Evaluasi Input}

Hasil penelitian menunjukkan bahwa indikator latar belakang pendidik atau dosen menunjukkan sebanyak $56.25 \%$ termasuk pada kategori baik, artinya sebagian besar dosen mampu mengoperasikan pembelajaran melalui e-learning, meskipun dari segi kualifikasi pendidikan dan kompetensi dosen tidak terfokus pada penggunaan teknologi pada pembelajaran. Ditinjau dari latar belakang kemampuan mahasiswa sebagian besar mahasiswa yakni sebanyak $64.28 \%$ termasuk pada kategori baik, artinya pembelajaran dengan e-learning mendapat sambutan yang responsive dari mahasiswa, terdapat interaksi dan partisipasi yang aktif dari mahasiswa dalam belajar. Dosen dapat menyampaikan materi baik secara audio, tekstua maupun video pembelajaran melalui media ini begitupula mahasiswa dapat dengan nyaman dan lebih leluasa menyampaikan pendapatnya diforum diskusi yang tersedia pada platform e-learning. Beberapa kemampuan yang telah dimiliki oleh mahasiswa adalah kemampuan memanfaatkan internet untuk mencari materi dalam perkuliahan, mengunduh materi dalam bentuk teks dari internet untuk menunjang perkuliahan, mengunduh informasi berbentuk audio/video dari internet untuk menunjang perkuliahan dan dapat mengirim pesan email menggunakan layanan internet untuk perkuliahan (As-salam et al., 2020). Jika dilihat dari indicator ketersediaan sarana prasarana pendukung pelaksanaan pembelajaran dengan $e$-learning didapatkan sebanyak $52.67 \%$ termasuk pada kategori baik, artinya sebagian responden telah memiliki perangkat yang mendukung dalam pelaksanaan pembelajaran dengan e-learning seperti smartphone atau laptop. Dengan bentuk yang lebih kecil dan simple sehingga lebih mudah dan praktis dibawa kemana-mana memungkinkan smartphone menjadi sarana yang lebih banyak dipilih oleh mahasiswa sebagai perangkat pembelajaran disamping fungsi lain sebagia sarana hiburan. Namun yang menjadi masalah bahwa tidak semua siswa siap dengan hal ini. Dengan diharuskannya memiliki android dan kuota internet orang tua/ wali siswa harus menanggung beban tambahan dan tentu saja berdampak pada biaya Pendidikan yang semakin mahal (Sya et al., 2021). Indikator terakhir yakni ketersediaan perangkat pembelajaran berupa silabus dan rencana pembelajaran sudah berada pada katergori baik yaitu sebanyak $63.39 \%$ artinya persiapan pembelajaran telah dilakukan dengan baik, mahasiswa dapat mengakses rencana pembelajaran dalam satu semester kedepan dengan mudah.

\section{3) Evaluasi Proses}

Jika dilihat dari komponen input pada kelima indikator maka rata-rata sudah tegolong baik. Proses pembelajaran melalui e-learning termasuk kategori baik yakni $67.26 \%$ artinya sebagian besar dosen maupun mahasiswa mendukung bahwasanya penyapaian materi, pennyampaian tugas serta pelaksanaan evaluasi dilaksanakan melalui e-learning. Begitu pula halnya dengan aktivitas pendidik dalam pelaksanaan pembelajaran e-learning termasuk kategori baik sebanyak $77.67 \%$, semua dosen telah menggunakan $e$ learning dalam mengajar dan mampu mengoperasikan e-learning, meskipun pada kenyataannya dosen berupaya memenuhi tuntutan itu dengan belajar mandiri (otodidak). Media pembelajaran memegang peranan penting dalam pembelajaran terutama dalam pembelajaran daring. Media pembelajaran harus jelas, mudah diterima mahasiswa dan mampu menjembatani gap yang terjadi dan hilangnya nuansa pembelajaran yang biasa dilaksanakan didalam kelas (Astuti, 2020). Dari segi aktivitas mahasiswa sebanyak $68.45 \%$ termasuk kategori baik artinya hampir semua mahasiswa sudah pernah belajar menggunakan e-learning dan mampu mengoperasikannya, meskipun dari indicator kendala dan hambatan yang dijumpai dalam pelaksanaan $e$ learning hanya $49.1 \%$ termasuk kategori baik artinya masih terdapat hambatan dalam pelaksanaannya namun pengguna dalam hal ini dosen dan mahasiswa telah mampu mengatasi hambatan dan kendala yang dihadapi pada saat belajar menggunakan e-learning. Hambatan yang dimaksud dapat berupa terbatasnya kuota yang dimiliki oleh mahasiswa serta ketersediaan jaringan internet yang mendukung, sehingga kondisi ini seringkali mengganggu proses pembelajaran, bayak mahasiswa yang tidak bisa join atau harus join secara berulangulang. Seperti penelitian yang dilakukan oleh Wicaksana (2020) mayoritas dari mereka sangat jenuh dan kurang paham ketika kuliah menggunakan aplikasi WhatsApp. Ketika Menggunakan aplikasi video conference 
zoom meeting mereka juga merasa kurang bersemangat karena terkendala kuota. Kuota yang dibutuhkan dalam menggunakan zoom meeting sangat besar bagi mahasiswa. Mereka merasa keberatan serta terkadang ada beberapa mahasiswa yang tidak mendapatkan cukup sinyal dalam menggunakan aplikasi tersebut. Kondisi ini jika dibiarkan lambat laun tentu dapat menjadi beban psikologis bagi mahasiswa. Penelitian yang dilakukan oleh Jatira \& S (2021) yang mengatakan bahwa pertama pembelajaran daring dimasa pandemi Covid 19 ini menyebabkan peserta didik mengalami stress, kedua pembiasaan pembelajaran daring ini menyebabkan peserta didik menjadi bosan dan pemalas dikarenan beberapa gangguan yang mungkin terjadi dalam pembiasaan pembelajaran daring. Hal ini sejalan dengan hasil penelitian yang dilakukan oleh Bengkulu (2021) yang mengatakan bahwa e-learning merupakan alternatif pembelajaran ditengah masa pandemi dan persepsi mahasiswa mengenai pembelajaran daring berada pada kategori baik. Partisipasi peserta didik merupakan salah satu masalah dalam pembelajaran berbasis e-learning. Akan tetapi, masih memperhatikan kualitas pembelajaran berdasarkan standar yang diterima oleh mahasiswi. Hal tersebut, dilakukan dengan memastikan bahwa mahassiwi memiliki akses internet yang memadai, pada saat pembelajaran berbasis $e$ learning(Susanti et al., 2020). Begitupun dari segi indicator solusi yang diharapkan untuk memperlancar proses pembelajaran e-learning sebagian besar yakni 56.25\% termasuk kategori baik, artinya pengguna sebenarnya sudah berupaya mencari solusi atas hambatan yang dijumpai namun hal tersebut perlu mendapat perhatian serius dari lembaga untuk menindaklanjuti hal tersebut, misalnya memfasilitasi adanya pelatihan bagi dosen tentang penggunaan teknik dan media online dalam pembelajaran, menyiapkan konten-konten pembelajaran interaktif, diadakannya sosialisasi dan penyegaran secara kontinyu tetntang pemanfaatan $e$ learning Undiksha bagi segenap civitas akademika dalam menunjang pembelajaran. Kesiapan pelaksanaan pembelajaran dengan $e$-learning dapat dilihat dari tiga dimensi, yaitu motivasi untuk menggunakan $e$-learning, kompetensi atau kemampuan yang cukup untuk mengelola dan mengikuti pembelajaran e-learning, dan sumberdaya yang meliputi fasilitas, akses, dan teknologi yang memadai (Hanum, 2013).

\section{4) Evaluasi Produk}

Evaluasi produk pada penelitian ini meliputi: indikator pertama yakni hasil pembelajaran didapatkan bahwa $63.69 \%$ termasuk kategori baik, hal ini menunjukkan bahwa hasil belajar yang diperoleh oleh mahasiswa sudah baik, capaian pembelajaran yang diperoleh sudah baik dan sesuai dengan yang diharapkan. Namun meskipun demikian penilaian hasil belajar tetap harus mempertimbangkan indicator penilaian, dimana penilaian harus dilakukan dengan proporsi yang seimbang baik dari segi proses maupun dari segi hasil diakhir pembelajaran, tidak hanya menumpuk pada pembebanan tugas-tugas mata kuliah saja tanpa ada feedback yang berarti. Penelitian yang dilakukan oleh Prabandari \& Sumarni (2020) menunjukkan bahwa sebagian besar mahasiswa masih belum puas dengan metode pembelajaran e-learning. Oleh karena itu diharapkan dosen lebih variatif dalam melakukan pembelajaran e-learning dan memperhatikan beban tugas mahasiswa agar tetap seimbang sesuai kondisi dan kebutuhan pembelajaran. Indikator kedua yakni dampak pembelajaran dengan e-learning termasuk pada kategori baik yakni $63.83 \%$, hal ini menandakan bahwa pembelajaran dengan e-learning memberikan dampak yang baik bagi dosen maupun mahasiswa. Mahasiswa dan dosen memahami dengan baik bagaimana caranya mempersiapkan pembelajaran dengan e-learning, kemudian melaksanakan pengajaran melalui e-learning serta melakukan evaluasi terhadap hasil belajar mahasiswa melalui $e$-learning. Jika dilihat secara umum penggunaan e-learning diawal pembelajaran membutuhkan persiapan yang lebih rumit, mulai dari memilih platform yang digunakan, bagaimana mengoperasikannya, menyiapkan materi perkuliahan agar menarik dan interaktif, menyiapkan alat evaluasinya hingga akhirnya melakukan penilaian bagi capaian pembelajaran mahasiswa. Namun ketika semua hal itu sudah tersetting di system dengan baik maka pengoperasiannya akan jauh lebih mudah, mahasiswa dapat mengakses materi maupun penjelasan dosen secara berulang-ulang begitu pula dosen lebih mudah melakukan penilaian baik dari sikap dan partisipasi mahasiswa dalam pembelajaran berikut hasil penilaian melalui sistem. Pada kondisi ini 
sangat dibutuhkan penguasaan teknologi yang baik bagi dosen dan mahasiswa, dengan pembelajaran $e$ learning memaksa baik dosen maupun mahasiswa untuk terus belajar dengan menggunakan teknologi sebagai basic dalam proses pelaksanaannya. Dari penilaian yang dilakukan pada masing-masing komponen memang ditemukan bahwasanya pembelajara dengan e-learning memiliki cukup banyak tantangan baik bagi dosen maupun mahasiswanya sendiri. Metode pembelajaran daring yang efektif dengan memperhatikan aspek-aspek seperti: menggunakan media pembelajaran yang sesuai, strategi pembelajaran (Instructional Strategy) yang baik, Aktivitas pembelajaran yang variatif, dan sumber belajar (Learning Resources) yang luas akan dapat mencapai tujuan pembelajaran dan menjadikan hasil belajar mahasiswa berada pada kategori baik.(Amran et al., 2021). Secara keseluruhan dari hasil evaluasi yang telah dilakukan kini telah didapatkan suatu informasi secara holistic bahwasanya e-learning tentu masih sangat dibutuhkan sebagai media pembelajaran terlebih pada situasi pandemic seperti saat ini, hanya saja informasi yang didapat ini menjadi acuan bagi prodi khususnya untuk meningkatkan kualitas pembelajaran melalui e-learning itu sendiri mulai dari sumber daya pendidiknya yakni dalam hal ini dosen harus terus meningkatkan kemampuan diri untuk mengembangkan keterampilan mengelola pembelajaran dengan e-learning begitu juga mahasiswa aktif belajar secara mandiri dan terlebih lagi adanya suatu suppot system yang mumpuni, yakni akses internet yang mudah dan cepat didapat yang disediakan oleh lembaga secara gratis atau bahkan perlu dipertimbangkan adanya banyuan kuota internet untuk belajar bagi mahasiwa. Dengan demikian mahasiswa akan semakin termotivasi mengikuti pembelajaran meskipun secara daring dan satu hal yang menjadi keterbatasan pada penelitian ini adalah lingkup yang diamati terbatas pada pembelajaran teori mengingat pembelajaran secara praktika memerlukan metode yang lebih riil/ nyata sehingga memudahkan mahasiswa untuk menguasai keterampilan yang diajarkan.

\section{KESIMPULAN}

Pembelajaran dengan e-learning merupakan suatu solusi sekaligus tantangan berat yang harus dihadapi pada situasi pandemic seperti saat ini. Dari penelitian yang telah dilakukan secara mendetail meliputi komponen konteks, input, proses dan produk didapatkan hasil bahwa penyelenggaraan e-learning khusuunya di Prodi D3 Kebidanan FK Undiksha telah berjalan cukup baik meskipun ada beberapa kendala yang masih harus ditindaklanjuti. Beberapa kendala yang dimaksud diantaranya dari segi konteks yakni lingkungan pendukung pembelajaran masih harus terus mendapat perhatian, ketersediaan jaringan internet yang baik, sharing room dengan anggota keluaga lain tentu merupakan hal mendukung terselenggaranya proses pembelajaran dengan e-learning ini. Dari segi Input tentu kemampuan dosen dan mahasiswa juga perlu mendapat perhatian. Kemampuan dosen dan mahasiswa dalam mengoperasikan e-learning harus terus ditingkatkan baik dengan memfasilitasi dosen mengikuti pelatihan tentang strategi pembelajaran daring ataupun sosialisai penggunaan e-learning yang telah dimiliki oleh lembaga. Dari segi proses dalam pelaksanaan pembelajaran dosen juga harus kreatif dalam menyiapkan konten pembelajaran serta memilih media yang tepat sehingga tetap dapat menumbuhkan semangat dan interaksi dengan mahasiswa. Begitupula dari segi produk meskipun secara umum hasil belajar yang diperoleh oleh mahasiswa baik namun sangat perlu untuk melakukan penyesuaian kembali antara capaian pembelajaran mata kuliah dengan metode evaluasi yang digunakan.

\section{UCAPAN TERIMA KASIH}

Puji syukur kehadapan Tuhan Yang Maha Esa karena berkat rahmat dan tuntunanNya, artikel penelitian yang berjudul "Evaluasi Pemanfaatan E-Learning pada Pembelajaran Teori di Prodi D3 Kebidanan Fakultas Kedokteran Undiksha" ini dapat penulis selesaikan tepat waktu. Dalam penyusunan artikel ini tentunya tidak terlepas dari bantuan dan dukungan berbagai pihak yang telah dengan tulus ikhlas memberikan 
4504 Evaluasi Pemanfaatan E-Learning pada Pembelajaran Teori di Prodi Kebidanan Fakultas Kedokteran Undiksha - Ni Ketut Erawati, Made Juliani, Ni Wayan Dewi Tarini

DOI: https://doi.org/10.31004/edukatif.v3i6.1462

bimbingan, motivasi, maupun fasilitas pendukung lainnya. Untuk itu, melalui kesempatan ini penulis menyampaikan ucapan terima kasih yang sebesar-besarnya kepada Bapak Rektor, Dekan Fakultas Kedokteran Universitas Pendidikan Ganesha, Ibu Koorprodi D3 Kebidanan atas kesempatan dan dukungan fasilitas yang diberikan, Tim Reviewer Edukatif Jurnal Ilmu Pendidikan Universitas Pahlawan Tuanku Tambusai atas masukan dan saran demi kesempurnaan artikel ini serta adik-adik mahasiswa Prodi D3 Kebidanan khususnya Semester IV TA.2019/2020 atas partisipasinya dalam penelitian ini, Semoga Tuhan Yang Maha Esa memberikan karunia atas semua budi baik yang telah diberikan. Artikel penelitian ini dengan segala keterbatasannya, dipersembahkan kepada dunia pendidikan dan semoga ada manfaatnya.

\section{DAFTAR PUSTAKA}

Amran, H. F., Suryani, L., Studi, P., \& Kebidanan, S. (2021). Efektivitas Metode Pembelajaran Daring ( Dalam Jaringan ) Pada Mata Kuliah Asuhan Kebidanan. 5(2).

Arikunto, S. (2008). Evaluasi Program Pendidikan. Bumi Aksara.

Arikunto, S. (2011). Prosedur Penelitian: Suatu Pendekatan Praktik (Ed.Rev.Vi). Rineka Cipta.

As-Salam, J., No, V., Desember, J., Penerapan, E., \& Model, E. M. (2020). Abdullah Syifa Di Program Studi Psikologi Islam Iain Pontianak Abdullah Syifa Program Studi Psikologi Islam Iain Pontianak, Indonesia Email : Abdullah.Syifa@Iainptk.Ac.Id.4(2), 180-194.

Astuti, L. D. (2020). The Potret Evaluasi Pembelajaran Daring (E-Learning) Mahasiswa Kesehatan Dimasa Pandemi Covid-19. Jurnal Kebidanan, 9(2), 25-33. Https://Doi.Org/10.47560/Keb.V9i2.246

Bengkulu, U. D. (2021). Edukatif: Jurnal Ilmu Pendidikan Persepsi Mahasiswa Terhadap E-Learning Berbasis Zoom Meeting Pada Mata Kuliah Telaah Kurikulum Sekolah. 3(6), 4145-4151.

Bhakti, Y. B. (2017). Evaluasi Program Model Cipp Pada Proses Pembelajaran Ipa. Jipfri (Jurnal Inovasi Pendidikan Fisika Dan Riset Ilmiah), 1(2), 75-82. Https://Doi.Org/10.30599/Jipfri.V1i2.109

Gede, D., \& Divayana, H. (N.D.). Evaluasi Pemanfaatan E-Learning Menggunakan Model Cse-Ucla.

Hanum, N. S. (2013). Keefektifan E-Learning Sebagai Media Pembelajaran (Studi Evaluasi Model Pembelajaran E-Learning Smk Telkom Sandhy Putra Purwokerto). Jurnal Pendidikan Vokasi, 3(1), 90102. Https://Doi.Org/10.21831/Jpv.V3i1.1584

Islam, U., Antasari, N., Learning, B., \& Belajar, H. (2021). Edukatif: Jurnal Ilmu Pendidikan Hubungan Penggunaan Model Pembelajaran Blended Learning Terhadap Hasil Belajar Matematika Siswa Sekolah Dasar. 3(6), 3794-3801.

Jatira, Y., \& S, N. (2021). Fenomena Stress Dan Pembiasaan Belajar Daring Dimasa Pandemi Covid-19. Edukatif: Jurnal Ilmu Pendidikan, 3(1), 35-43. Https://Doi.Org/10.31004/Edukatif.V3i1.187

Ningsih, S. (2020). Persepsi Mahasiswa Terhadap Pembelajaran Daring Pada Masa Pandemi Covid-19. Jinotep (Jurnal Inovasi Dan Teknologi Pembelajaran): Kajian Dan Riset Dalam Teknologi Pembelajaran, 7(2), 124-132. Https://Doi.Org/10.17977/Um031v7i22020p124

Oemar Hamalik. (2009). Perencanaan Pengajaran Berdasarkan Pendekatan Sistem (Cetakan 8). Bumi Aksara.

Prabandari, F., \& Sumarni, S. (2020). Pengaruh Persepsi E-Learning Terhadap Kepuasan Mahasiswa Kebidanan Dalam Masa Pandemik Di Stikes Muhammadiyah Gombong. Jurnal Ilmiah Kesehatan Keperawatan, 16(1), 44. Https://Doi.Org/10.26753/Jikk.V16i1.401

Rahman, M. A., Amarullah, R., \& Hidayah, K. (2020). Evaluasi Penerapan Model Pembelajaran E-Learning Pada Pelatihan Dasar Calon Pegawai Negeri Sipil. Jurnal Borneo Administrator, 16(1), 101-116. Https://Doi.Org/10.24258/Jba.V16i1.656 
4505 Evaluasi Pemanfaatan E-Learning pada Pembelajaran Teori di Prodi Kebidanan Fakultas Kedokteran Undiksha - Ni Ketut Erawati, Made Juliani, Ni Wayan Dewi Tarini

DOI: https://doi.org/10.31004/edukatif.v3i6.1462

Riyanda, A. R., Herlina, K., \& Wicaksono, B. A. (2020). Evaluasi Implementasi Sistem Pembelajaran Daring Fakultas Keguruan Dan Ilmu Pendidikan Universitas Lampung. Jurnal Ikra-Ith Humaniora, 4(1), 66-71. Https://Journals.Upi-Yai.Ac.Id/Index.Php/Ikraith-Humaniora/Article/View/669

Sugiyono. (2011). Metode Penelitian Kuantitatif Dan Kualitatif Dan R\&D. Alfabeta.

Susanti, A. I., Sari, A. N., \& Mandiri, A. (2020). Motivasi Belajar Mahasiswi Kebidanan Terhadap Pembelajaran Modul Asuhan Kehamilan Berbasis E-Learning Di Era Pandemi Covid-19. Jurnal Kebidanan Malahayati, 6(4), 485-492. Https://Doi.Org/10.33024/Jkm.V6i4.2993

Sya, A., Purwanto, A., \& Astra, I. M. (2021). Edukatif: Jurnal Ilmu Pendidikan Tantangan Guru Dalam Penggunaan Metode Pembelajaran Jarak Jauh ( Pjj ). 3(6), 3877-3883.

Syswianti, D., Suryani, N., \& Wahyuni, T. (2020). Evaluasi Pembelajaran Daring Dengan Menggunakan Aplikasi Zoom Di Masa Pendemi Covid-19 Pada Mata Kuliah Pengantar Asuhan Kebidanan. Jurnal Medika Cendikia.

Wibawanto, H. (2017). Teknologi Informasi Dan Komunikasi Dalam Pembelajaran Sains. 1-12.

Wicaksana, E. (2020). Efektifitas Pembelajaran Menggunakan Moodle Terhadap Motivasi Dan Minat Bakat Peserta Didik Di Tengah Pandemi Covid -19. Eduteach: Jurnal Edukasi Dan Teknologi Pembelajaran, 1(2), 117-124. Https://Doi.Org/10.37859/Eduteach.V1i2.1937 